\title{
The effect of nicotine per inhalation on the diameter and epithelium thickness of the seminiferous tubules of rats
}

\author{
Y.S. En ${ }^{1}$, H. Primarizky ${ }^{2}$, W. Widjiati ${ }^{3}$ and E.M. Luqman ${ }^{4 *}$ \\ ${ }^{1}$ Faculty of Veterinary Medicine, ${ }^{2}$ Department of Veterinary Clinic, ${ }^{3,4}$ Department of Veterinary Anatomy, Faculty of \\ Veterinary Medicine, University of Airlangga, Surabaya, East Java, Indonesia, ${ }^{*}$ corresponding authou. \\ Email: ${ }_{1}^{1}$ shien199718@gmail.com, ${ }^{2}$ hardany-p@fkh.unair.ac.id, ${ }^{3}$ widjiati@fkh.unair.ac.id, ${ }^{4}$ epy-m-1@fkh.unair.ac.id,
}

(Received May 20, 2019; Accepted June 13, 2019)

\begin{abstract}
This study aimed to assess the level of testicular damage by observing the changes in the diameter and epithelium thickness of seminiferous tubules in rats that exposure to nicotine per inhalation. Thirty adult male rats were used and divided into five equal groups and treatment as follows for 20 days; Control group $\mathrm{NaCl} 0.9 \%, \mathrm{P} 1$ nicotine $0.5 \mathrm{mg} / \mathrm{kg}, \mathrm{P} 2$ nicotine $1.0 \mathrm{mg} / \mathrm{kg}, \mathrm{P} 3$ nicotine $2.0 \mathrm{mg} / \mathrm{kg}$ and $\mathrm{P} 4$ nicotine $4.0 \mathrm{mg} / \mathrm{kg}$. All groups were given treatment per inhalation for twenty days. At the end of treatment and the rats were sacrificed testes were collected for histopathological preparation. The testes were processed for routine paraffin embedding and staining and the sections were examined for histopathological changes. There results showed that nicotine administration induced varying degrees of structural damage to the seminiferous tubules, as the decreased in diamater and epithelium thickness of seminiferous tubules. The diameter and epithelium thickness of seminiferous tubules in four experimental groups reduced compared to the control group. This study proves that nicotine administration does decreases the spermatogenesis of rats by reducing the diameter and epithelium thickness of seminiferous tubules in testes. It also proves that the level of testicular damage is directly proportional to the dosage of nicotine administrated to male rats.
\end{abstract}

Keywords: Nicotine, Seminiferous tubules diameter, Epithelium thickness Available online at http://www.vetmedmosul.com, (C) 2020, College of Veterinary Medicine, University of Mosul. This is an open access article under the CC BY 4.0 license (http://creativecommons.org/licenses/by/4.0/).

$$
\begin{aligned}
& \text { تأثير النيكوتين عن طريق الاستششاق على قطر وسمك ظهارة النبيبات المنوية للجرذان } \\
& \text { إين'، برايمارازكي'، وجاتي " و لقمان؛ } \\
& \text { ' كلية الطب البيطري، ' فرع السريريات البيطري، r،؛ فرع التشريح البيطري، كلية الطب البيطري، جامعة إيرلانكا، سورابيا، إندنوسيا }
\end{aligned}
$$

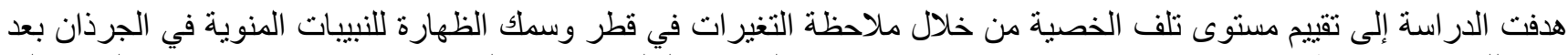

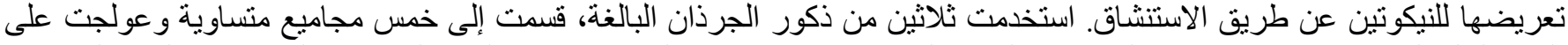

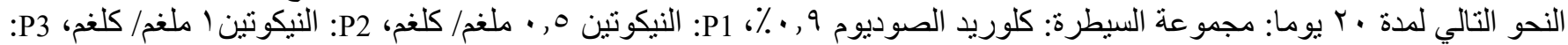

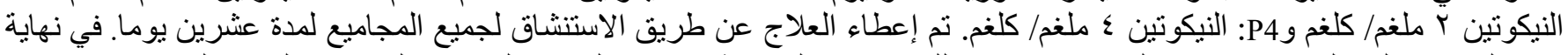

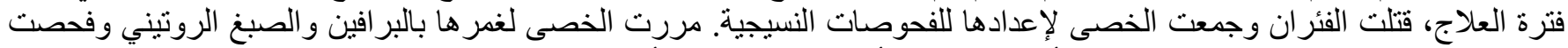

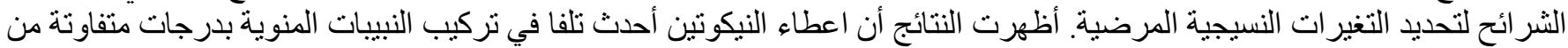

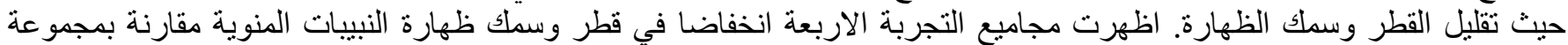

$$
\begin{aligned}
& \text { السيطرة. اثبتت الدر اسة أن التعرض للنيكوتين يقلل من تكوين الحيو انات المنوية في الجرذان عن طريق تقليل القطر وسمك الظهارة للنبيبات }
\end{aligned}
$$

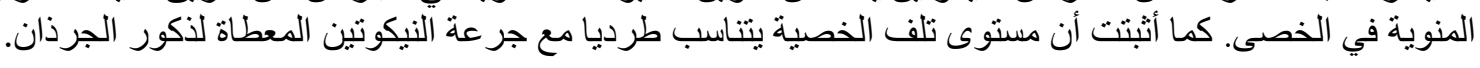




\section{Introduction}

Cigarette smoking is a leading contributor to illness and death among world populations nowadays. Although cigarette smoking is proven to cause many negative effect, people continue to consume cigarettes on a regular basis. Approximately one third of world's population 15 years or older smokes cigarettes daily (1). The situation got worsen during in early 2011, electronic cigarettes (e-cigarettes) and other electronic vaping products are invented and highly used among the adolescents. E-cigarettes works by heating a liquid to generate an aerosol, commonly called a vapor, that the user inhales. Using e-cigarettes is sometimes called vaping (2). E-cigarette use can be detrimental to adolescents because it exposes them to harmful constituents in aerosol such as pure nicotine, a chemical that contributes to addiction and harms adolescent brain development. Adolescents' reports of using nicotine-containing versus nicotine-free e-cigarettes are inconsistent. A study found that, among youths who used e-cigarettes, 29\% typically used e-liquid without nicotine, 37\% used e-liquid with nicotine, and $34 \%$ did not know if the e-liquid they used contained nicotine (3). The safety of e-cigarettes has not yet been well established. A recent systematic literature review concluded that the current data do not warrant health concerns, at least according to the standards used to guarantee workplace safety (4).

Nicotine, one of the most common component abuse through cigarette and is a major public health problem. It is highly toxic and absorbed quickly through the respiratory tract, mouth mucosa and skin during smoking (5). A number of passive smokers are also negatively affected when they inhale side-stream smoke from burning cigarettes (second hand smoke). Cigarette smoking has been linked strongly to following illness such as heart disease, stroke, hypertension, respiratory disease, infertility and even cancer (6). It has been proven that a smoker who constantly smokes for many years will be examined to contain high nicotine level in his blood as nicotine travels in blood circulation. The nicotine will eventually spreads into entire body system including reproductive system (7). Furthermore, the fact that cigarette smoke is a known somatic cell mutagen and carcinogen, there is a major concern that smoking may adversely affect male reproductive health (8). Many research suggest that $60-65 \%$ of men suffers lower quality of sperm caused by the habit of smoking. For example, spermatozoa from smokers is proven have reduced fertilizing capacity, and displays a lower implantation rates (9). The influence of cigarette smoke can decrease the quality (quantity, motility and morphology) of sperm and causes damage to the cells of the testes (10). Exposure to cigarette smoke can inhibit spermatogenesi characterised by a decrease in the number of spermatogonium cells, primary spermatosit, spermatid cells and the viability of spermatozoa (11). Cigarette smoking has been shown to disrupt the mechanism between hypothalamus, anterior pituitary and testicles, affecting the formation of gonadotropins (GnRH) include Folicle Stimulating Hormone (FSH) and Luteinizing Hormone (LH) that works during spermatogenesis. Nicotine treatment cause a significant decrease in the mean serum FSH and testosterone. Imbalance mechanism of reproductive hormones will eventually affects the mechanism of spermatogenesis in testis (12). Infertility is a major health issue among couples of child bearing-age and a problem for future human populations. In spite of the growing knowledge of adverse reproductive effects of smoking on reproducion, it is relatively unclear whether or not; nicotine has the same effects and mechanism of action on seminiferous tubules. Over years there are many research about nicotine on testis (5), however there are only a few research talk about the effect of nicotine on the diameter and epithelium thickness of seminiferous tubules.

Therefore, this Research was aimd to determine that if the exposure of nicotine per inhalation will decrease the diameter of seminiferous tubules of male rats. Also, this research benefits to provide detailed data and information about the inhalation of nicotine could be affect the seminiferous tubules in testis and induce reproductive disorder of male rats. This research is expected so that it can give information about the inhalation of nicotine could decrease the diameter and epithelium thickness of the seminiferous tubules and induce reproductive disorder on male fertility.

\section{Materials and methods}

\section{Materials}

The experimental design used in this study is completely randomized design. This research was conducted at the Laboratorium of Experimental Animal at Faculty of Veterinary Medicine in University Airlangga, from July 2018 till September 2018. The study was approved by Faculty of Veterinary Medicine Animal Ethics Committee. The testes samples were collected from the animals after considerations in accordance to Faculty of Veterinary Medicine Animal Ethics Committee related to animal handling were observed to ensure no discomfort or pain to animal during sampling (No: 2.KE.061.04.2018)

This research carried out on 30 male rats Rattus norvegicus aged around 2-3 months, have an average body weight 140 - 160 gram obtained from Institute of Integrated Research and Testing Universitas Gajah Mada.

In this research, pure liquid nicotine is given to all four experimental groups by inhalation using a special designed smoking chamber to produce nicotine mist. The nebulizer 
(Omron Nebulizer NE C28) will then uses oxygen, compressed air or ultrasonic power to break up nicotine solutions and suspensions into small aerosol droplets that can be directly flows into the gas chamber through the tubes. The main equipment that used in this research is a specially designed smoking chamber made up of glass measuring $38 \mathrm{~cm} \times 28 \mathrm{~cm}, 5 \mathrm{~cm} \times 22.5 \mathrm{~cm}$, equipped with ventilation, with 2 tubes connecting to the nebulizer (filled with pure nicotine solution).

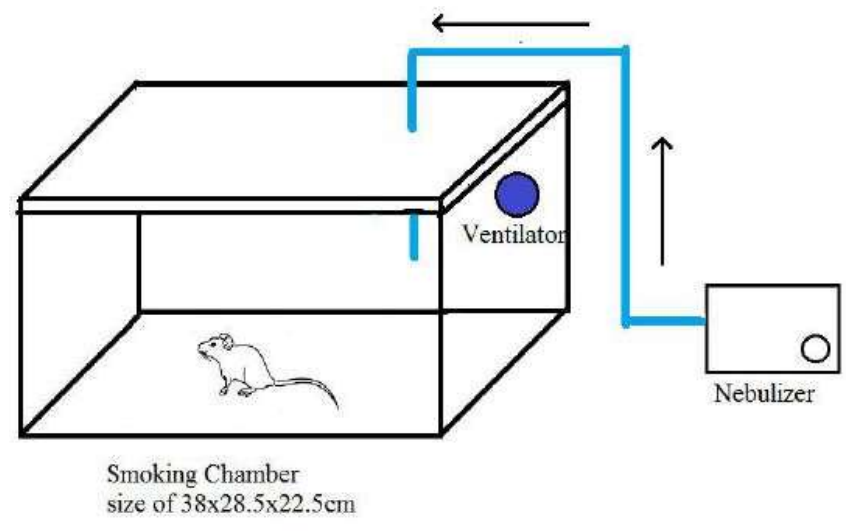

Figure 1: The smoking chamber used in research.

\section{Methods}

Before the experiment is being conducted, the male rats were first exposed for adaptation for one week. Throughout the process of adaptation, the male rats were given normal rat feed and drinking water. The animals were randomly categorized and divided equally into five groups, with six animals per group and their initial body weights were recorded. The animals of each group were treated as follows. $\mathrm{C}(-)$ : as the control group. This group was given $\mathrm{NaCl} 0.9 \%$ per inhalation by using a nebulizer connected to a smoking chamber. Treatment groups (P1, P2, P3, and P4) were treated respectively with: $0.5,1.0,2.0$ and $4.0 \mathrm{mg} / \mathrm{kg} \mathrm{BW}$ of nicotine per inhalation using nebulizer connected to smoking chamber (13). All treatment were conducted for 30 minutes at $10.00 \mathrm{am}$ till $10.30 \mathrm{am}$ everyday in the lab of experimental animal for 20 days consecutively.

All male rats from all treatment group were anaesthetised by using ether per inhalation. The male rats were sacrificed by drawing all the blood from the heart and cutting the aorta. The testis of each rats were then collected. The procedure to make histopathology slides included tissue fixation, dehydration, clearing, impregnation, embedding, tissue slicing, incubation, staining, and mounting as HE Staining.
The diameter of seminiferous tubules were measured by using micrometer from software (Image Raster) with 100x magnification for total 5 random views. The roundest seminiferous tubules in each view was measured. The epithelium thickness of seminiferous tubules were measured by using micrometer from software with $400 \mathrm{x}$ magnification for total 5 same views for diameter previously. The epithelium thickness was measured from spermatogonium near basement membrane of seminiferous tubules until the spermatid. Data was analyzed using the analysis of variance $($ ANOVA) with $(p<0.05)$ and after a real difference was found then it was followed by Duncan's multiple range test (14). Data was analyzed using Statistical Analytic Software program (SPSS).

\section{Results}

The results showed a significant decrease in the mean diamater of seminiferous tubules that received nicotine treatment $4.0 \mathrm{mg} / \mathrm{kg}$ when compared with their control. However, treatment groups such as $0.5 \mathrm{mg} / \mathrm{kg}, 1.0 \mathrm{mg} / \mathrm{kg}$ and $2.0 \mathrm{mg} / \mathrm{kg}$ showed an insignificant decrease in their mean diameter of seminiferous tubules when compared with the control (Figure 2). Experimental group with a dose administration of nicotine $4.0 \mathrm{mg} / \mathrm{kg}$ showed lowest yield of data for the diameter of seminiferous tubules. In table 1 , a decrease in the diameter of seminiferous tubules at all experimental group with nicotine administration $0.5 \mathrm{mg} / \mathrm{kg}$, $1.0 \mathrm{mg} / \mathrm{kg}, 2.0 \mathrm{mg} / \mathrm{kg}$ and $4.0 \mathrm{mg} / \mathrm{kg}$ compared with the control group. The decline of the diameters of seminiferous tubules can be seen in Figure 2. The results showed a significant decrease decrease in the epithelium thickness after the administration of nicotine per inhalation In groups treated with $1.0,2.0$ and $4.0 \mathrm{mg} / \mathrm{kg}$ as compared with control and $0.5 \mathrm{mg} / \mathrm{kg}$ nicotine treated group.

Table 1: The diameter and epithelium thickness of seminiferous tubules of male rats

\begin{tabular}{lcc}
\hline \multirow{2}{*}{ Group } & \multicolumn{2}{c}{ Mean \pm SD } \\
\cline { 2 - 3 } & Diameter & Thickness \\
\hline C & $283.75 \pm 15.40^{\mathbf{b}}$ & $109.52 \pm 3.16^{\mathbf{a}}$ \\
P1 & $275.10 \pm 11.01^{\mathbf{b}}$ & $106.53 \pm 1.74^{\mathbf{a}}$ \\
P2 & $267.92 \pm 13.89^{\mathbf{b}}$ & $89.78 \pm 5.09^{\mathbf{b}}$ \\
P3 & $238.81 \pm 20.56^{\mathbf{b}}$ & $75.32 \pm 2.32^{\mathbf{c}}$ \\
P4 & $188.57 \pm 20.83^{\mathbf{a}}$ & $53.05 \pm 6.79^{\mathbf{d}}$ \\
\hline
\end{tabular}

Different alphabetical superscripts in the same column represent a significant difference $\mathrm{P}<0.05$. 


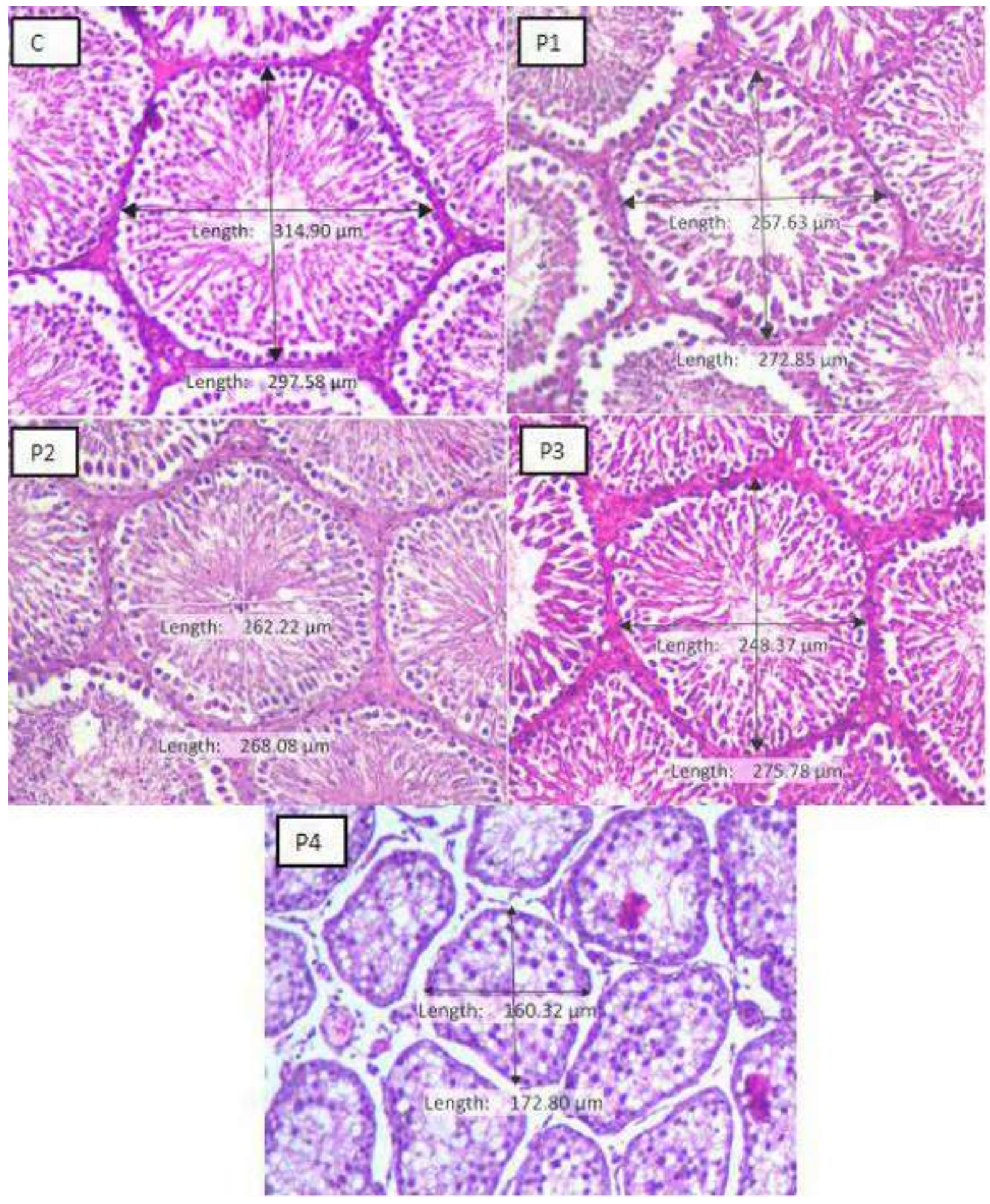

Figure 2: Representative microscopic image of seminiferous tubules of male rats from each treatment group after administration of nicotine per inhalation. P4 shows significant reduction in diameter of seminiferous tubules if compared with other experimental groups. HE stain, 100x. 


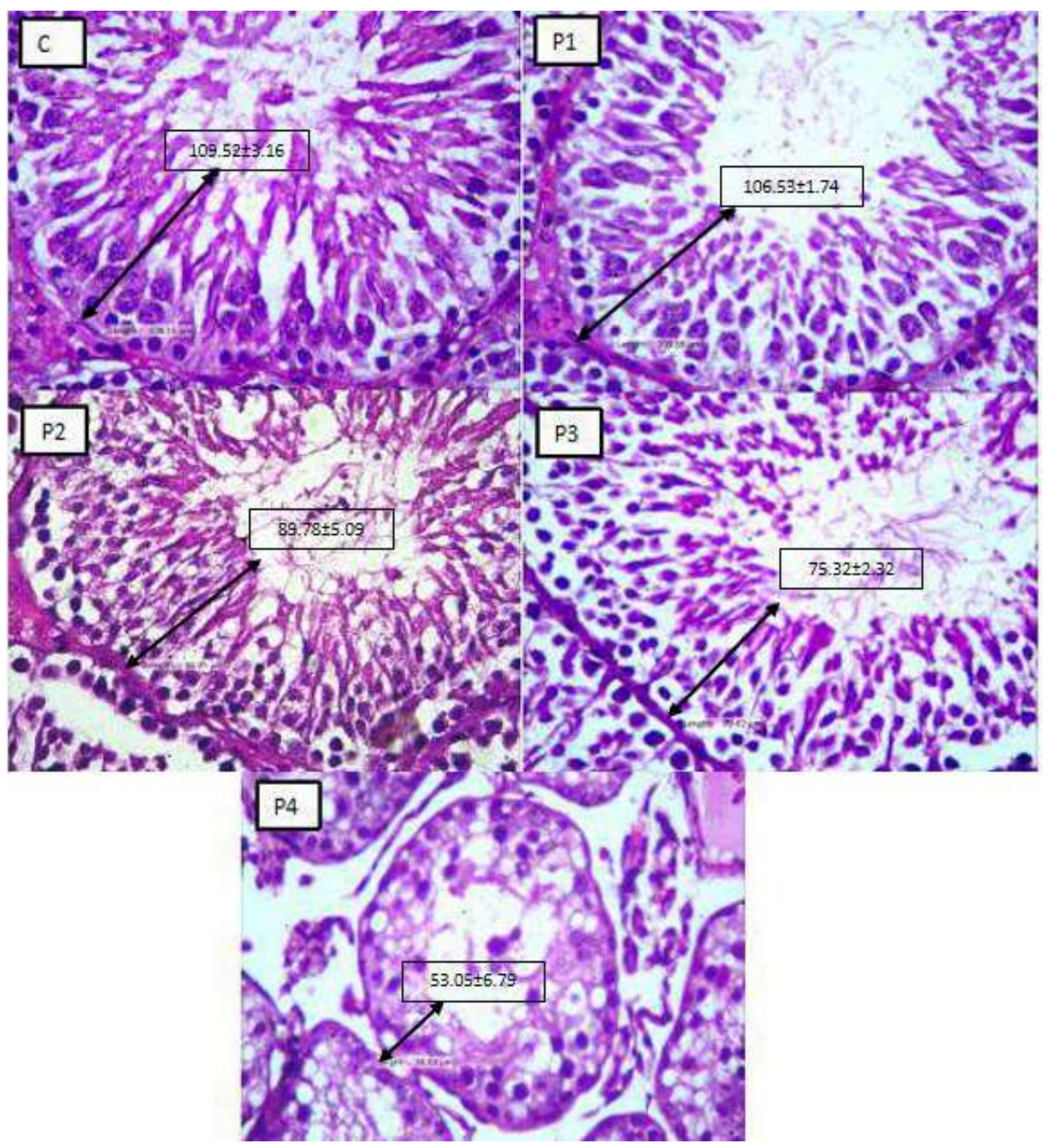

Figure 3: Representative microscopic image of seminiferous tubules of male rats from each treatment group as the results of nicotine administration per inhalation. HE stain, 400x.

\section{Discussion}

The results obtained from this studies is in consonance with earlier studies which suggest that nicotine in cigarette smoke can stimulate adrenal medulla to release catecholamines, which will affect the central nervous system, disrupting the feedback mechanism between hypothalamus, anterior pituitary and testicles (15). The relationship between the hypothalamus, anterior pituitary plays a major role in reproductive process. The hypothalamus regulates $\mathrm{GnRH}$ and signals the anterior pituitary. GnRh is a hormone which causes the release of two gonadotropin hormone named as Luteinizing Hormone (LH) and Follicle Stimulating Hormone (FSH) (16). Nicotine 
affects the work of the central nervous system by inhibiting the work of GnRH so that the formation of FSH and LH is inhibited. With the inhibition of FSH and LH formation, spermatogenesis runs abnormally. FSH, testosterone and LH are the major hormones that play an important role in spermatogenesis. Decrease in the number of spermatogenic cells causing decreasing in diameter and epithelium thickness of seminiferous tubules in the study is thought to be due to a decrease in these hormones. Cigarette smoking has been documented to act as an endocrine disruptor on the male hormone profile, specifically on FSH and testosterone. Testosterone is associated with FSH, which both also acts on the seminiferous tubules to initiate and maintain spermatogenesis. It is also well known that the production of testosterone is produced by Leydig cells under control of LH (17). Decrease of FSH observed with nicotine treatment could be due to increase of inhibin by the sertoli cell thus inhibiting the release of FSH from the anterior pituitary.

FSH stimulates the occurrence of spermatogenesis and testosterone in high intratesticular concentrations will maintain this process. Testosterone is needed to begin the process of meiosis of spermatocyte cells. Studies also state that testosterone plays a role in prophase division of the first meiosis stage, that is, when the metaphase division begins. The decrease in the number of spermatogenic cells is also supported by the statement that spermatocytes are very sensitive to external influences and tend to experience damage after the first meiotic prophase especially at the primary stage. If spermatocytes are damaged such as tubular atrophy, tubular necrosis, loss of intermedia cells, it will degenerate and become phagocytosed by Sertoli cells so that the number of spermatocytes decreases. Decreasing the number of spermatocytes causes the number of spermatids to also decrease because spermatocytes that experience second meiosis become decreased spermatids. Testosterone will maintain all stages of spermatid development (18).

The result of this research showed a non significant decline in the size of seminiferous tubules diameter in P1, P2 and P3 experimental groups, while a significant difference in diameter of the seminiferous tubules was found in group P4. The lowest diameter of seminiferous tubules also can be found on the same experimental group with the dose of $4.0 \mathrm{mg} / \mathrm{kg}$ nicotine. Although the present study used nicotine, the fluctuations of seminiferous tubules diameter are similar to the results of Güven et al which found that exposure to nicotine, cigarette smoke and/or polycyclic aromatic hydrocarbons are able to produce testicular atrophy, block spermatogenesis and alter sperm morphologic features in rats (19).

Experimental group with nicotine administration 4.0 $\mathrm{mg} / \mathrm{kg}$ shows lowest number of epithelium thickness of seminiferous tubules. The production of spermatozoa is low or no production of spermatozoa in the testis can decrease the epithelium thickness of seminiferous tubules, which means the production of spermatozoa affect the size of the diameter of seminiferous tubules (20). The relation between measurement of diameter and epithelium thickness of seminiferous tubules are inseparable due to the structure of seminiferous tubules that are composed of germinal cells and somatic cells that make up the germinative epithelium (21). According to few studies, the decrease of seminiferous tubules diameter occurs due to destruction of germinal cells from germininative epithelium, eventually decreasing the epithelium thickness of seminiferous tubules. The decreasing of both diameter and epithelium thickness may also occurs due to reduction of cells number that make up seminiferous tubules due to apoptosis (22).

Experimental groups with nicotine dosage of $1.0 \mathrm{mg} / \mathrm{kg}$ and $2.0 \mathrm{mg} / \mathrm{kg}$ shows a significant decline in epithelium thickness as compared between each other's, but shows non significant results in the diameter of seminiferous tubules. This occurs because the spermatogenesis process is affected, causing destruction of germinal epithelium and becomes thinner. However, the damage of epithelium thickness is still tolerable and have not caused the diameter of lumen of seminiferous tubules to shrink and decrease. On the other hand, experimental group with nicotine dosage of $4.0 \mathrm{mg} / \mathrm{kg}$ shows significant decrease on both epithelium thickness and diameter of seminiferous tubules as compared to other experimental groups is suspected to caused by major destruction of germinal cells from germinal epithelium, decreasing the epithelium thickness, and eventually caused the wall of seminiferous tubules to become thinner and collapse, thus decrease the diameter of seminiferous tubules.

\section{Conclusion}

In conclusion, nicotine inhalation inhibits spermatogenesis as represented by the reduction in diameter and thickness of seminiferous tubules.

\section{Acknowledgments}

The authors express sincere thanks to the Ministry of Research, Technology and Higher Education of the Republic of Indonesia for funding research and Dean Faculty of Veterinary Medicine for providing all necessary facilities and fund for conducting research work.

\section{References}

1. Zenzes MT, Reed TE, Casper RF. Effects of cigarette smoking and age on the maturation of human oocytes. J Hum Reprod. 2000;12(8):173641. DOI: https://doi.org/10.1093/humrep/12.8.1736

2. Drummond MB, Upson D. Electronic cigarettes potential harms and benefits. Annals ATS. 2014; 11(2): 236-242. DOI: https://doi.org/10.1513/AnnalsATS.201311-391FR

3. Morean ME, Kong G, Camenga DR, Cavallo DA, Krishnan SS. High school students' use of electronic cigarettes to vaporize cannabis. J 
Pediat Ohio. 2015;136(4):611-6. DOI: https://doi.org/10.1542/peds.2015-1727

4. Burstyn I. Peering through the mist: Systematic review of the chemistry of contaminants in electronic cigarettes tells us about health risks. BMC Public Heal. 2014;14(1):1-8. DOI: 10.1186/1471-2458-14-18.

5. Mishra A, Chaturvedi P, Datta S, Sinukumar S, Joshi P, Garg A. Harmful effects of nicotine: Review Article. Indian J Med Paediat Oncol. 2015;36(1):24-31. DOI: 10.4103/0971-5851.151771

6. John AA, Rajat SB. The pathophysiology of cigarette smoking and cardiovascular disease. J Am Coll Cardiol. 2004;43(10):1731-1737. DOI: 10.1016/j.jacc.2003.12.047

7. Al Mutairi SS, Shihab-Eldeen AA, Mojiminiyi OA, Anwar AA. Comparative analysis of the effects of hubble-bubble (Sheesha) and cigarette smoking on respiratory and metabolic parameters in hubblebubble and cigarette smokers. Respirol. 2006;11(4):449-55. DOI: 10.1111/j.1440-1843.2006.00873.x

8. Vine MF. Smoking and male reproduction: A Review. Int J Androl. 1996;19(6):323-37. DOI: https://doi.org/10.1111/j.1365-2605.1996.tb00523.x.

9. Ramlau HCH, Thulstrup AM, Olsen J, Bonde JP. Parental subfecundity and risk of decreased semen quality in the male fffspring: A follow-up study. Am J Epidemiol. 2008;167(12):1458-64. DOI:10.1093/aje/kwn076

10. Mahanem MA, Nor-Asmaniza, Phang HT. Effects of nicotine and coadministration of nicotine and vitamin $\mathrm{E}$ on testis and sperm quality of adult rats. Malays Appl Biol. 2006;35(2):47-52.

11. Aina N. Effect of exposure to cigarette smoke on spermatogenesis and quality of spermatozoa of mice. Makara Kesehatan. 2005; 12:1-10.

12. Oyeyipo IP, Raji Y, Bolarinwa AF. Nicotine alters male reproductive hormones in male albino rats: The role of cessation. J Hum Reprod Sci. 2013;6(1):40-4. DOI: 10.4103/0974-1208.112380
13. Adrien JAU, Kusumorini N, Agungpriyono S, Satyaningtijas AS, Boediono A. Changes in spermatozoa quality and number of spermatogenic cells in rats exposed to cigarette smoke. J Kedokteran Hewan. 2014;8(2):116-119.

14. Kusriningrum A. Basic Design of Trial and Complete Random Design. Faculty of Veterinary Medicine. $1^{\text {st }}$ ed. Surabaya. Universitas Airlangga; 2010. 53-92 p.

15. Anita N. Changes in the distribution of the seminal epithelial level, reduction in the number of spermatogenic cells and total testosterone hormone levels in mice (Mus musculus L) DDY strains that are smoked with clove cigarettes. [Tesis]. Graduate program Faculty of Medicine Universitas Indonesia. 2004.

16. Guyton AC. 1997. Medical Physiology. Jakarta: Medical Book Publisher. EGC.

17. Ramaswamy S, Weinbauer GF. Endocrine control of spermatogenesis: Role of FSH and LH/ testosterone. Spermatogen. 2014;4(2):996025.

18. Holdcraft RW, Braun RE. Hormonal regulation of spermatogenesis. Int J Androl. 2004;27:335-342 . DOI: 10.1080/21565562.2014.996025

19. Güven MC, Can B, Ergün A, Saran Y, Aydos K. Ultrastructural effects of cigarette smoke on rat testis. Eur Urol. 1999;36(6):645-9. DOI: $10.1159 / 000020061$

20. Gulkesen KH, Tibet E, Canan FS, Gulten K. Expression of extracellular matrix proteins and vimentin in test of azoospermic man: An immunohistochemical and morphometric study. Asian J Androl. 2002;4(1):55-60.

21. Hayati A. Spermatology. $1^{\text {st }}$ ed. Surabaya: Airlangga University Press; 2011. $105 \mathrm{p}$.

22. Ramandey I. Effect of Peroral Cadmium Giving on Testicular Weight, Seminiferus Tubule Diameter, Lumen Diameter of Seminiferus Tubules, and Epithelium of White Rat (Rattus norvegicus strain wistar) Epithelium. [Thesis]. Graduate program Universitas Airlangga Surabaya. 2005. 